\title{
Social Context and Resources Available to Iranian Foreign Language Learners of English
}

\author{
Ali Kazemi (Corresponding author) \\ Assistant Professor of Applied Linguistics, Dept. of English, School of Humanities, Yasouj University, Iran \\ Tel \& Fax: (+98) $7412221502 \quad$ E-mail: akazemi@yu.ac.ir \\ Iman Izadi \\ Dept. of English, School of Humanities, Yasouj, Iran
}

Received: 04-04-2013

doi:10.7575/aiac.ijalel.v.2n.4p.127
Accepted: 14-05-2013

Published: 01-07-2013

URL: http://dx.doi.org/10.7575/aiac.ijalel.v.2n.4p.127

\begin{abstract}
It has long been known that teaching and learning a language in an ESL context is by far easier than teaching and learning it in an EFL context and that learning a language must take place in a social context. Foreign language contexts are those in which students do not have enough opportunities for communication in the target language beyond their classroom settings whereas in second language contexts, the target language is readily available out there (Brown, 2001). Given the important role that language learning resources could potentially play in EFL contexts, in the present study an attempt is made to shed light on the resources which Iranian language learners rely on and to explore the possible resources which exist around them and of which not all of them are necessarily aware. To this end, a group of students studying in Iran Language Institute in Shiraz was chosen. The data of the study were gathered through a questionnaire and a semi-structured interview. The findings suggested that they rely on very few resources outside the classroom setting. In addition, it was revealed that in an EFL context, such as Iran, there is a range of resources which foreign language learners could rely on and which could present them with opportunities in all four language skills.
\end{abstract}

Keywords: foreign language learning, language learning resources, second language context, social context

\section{Introduction}

It is a known fact that teaching and learning a language in a second language context is much easier than teaching and learning it in a foreign context. Regarding the differences between second and foreign language learning, Stern (1983) believes that a non-native language learned and used within one country is considered as the second language, and a non-native language learned and used with reference to the speech community outside national or territorial boundaries is considered as a foreign language. He also holds that "a second language usually has official status or a recognized function within a country which a foreign language has not" (Stern, 1983, p. 16).

In line with Stern (1983), Brown (2001) also makes a distinction between foreign and second language learning context. He accentuates the environment outside the language classroom and points out that second language learning contexts are those in which the classroom target language is readily available out there while in foreign language contexts, students do not have ready-made contexts for communication beyond their classroom setting. Of course, attempts, such as establishing language clubs, special media opportunities, books, and so on, have been made to create opportunities to enrich the environment outside the classroom in foreign language contexts. However, in a typical second language context, students have a tremendous advantage, as they are exposed to an instant language laboratory twenty-four hours a day (Brown, 2001, p. 116). Needless to say, there is an enormous amount of variation among foreign language contexts in terms of the learning opportunities which they provide for language learners.

In a similar vein, Stern (1983) holds that the immediate or wider social environment can be analyzed for various factors which have certain effects on language education. They can be classified, as Spolsky et al. (1974) put it, into categories such as: "Linguistic, Sociocultural, Historical/Political, Geographical, Economic/Technological, and Educational". The influence of these factors on language teaching is not self-evident. A factor may or may not have an effect in a specific context. Some of these factors are believed to act as constraints in some contexts but at other times and in other situations, these same factors may enhance opportunities for language teaching and learning. In other words, in different language learning contexts, these factors may lead to different language learning resources and opportunities for both second and foreign language learners (Stern, 1983, p. 275).

Therefore, regarding the process of language teaching and learning, the concept of social context is considered to be of considerable significance. First, it must be pointed out that language itself must be related to a social context. In addition, for language teaching to be effective, it is important to relate language to society, because languages are learned and taught to pave the way for communication across language boundaries. Furthermore, society and culture are concepts that represent the people with whom the learners must establish communication (Stern, 1983, p. 283). 
Therefore, it is important to make the educational stake-holders aware of the factors which have far-reaching effects on the process of education in general and language education in particular.

Despite the importance of social context and its significant effects on language learning and teaching, to the researchers' best knowledge, no comprehensive study has yet been carried out in Iran regarding the impact of social context on Iranian foreign language learners and the resources available in such a context. Since Iranian foreign language learners are living in a context in which they have little exposure to English language, this study is concerned with the issues of L2 learners' access to language learning resources within this community.

\section{The Present Study}

Learning a language in a foreign context has proven to be more difficult than learning it in a second context; this is partly due to the resources available to language learners and the amount of time they spend on learning outside the classroom setting (Stern, 1983; Brown, 2001). Given the great difference which such resources make, this study is expected to shed light on the resources available to language learners and teachers in a foreign context, specifically in Iran. Moreover, it investigates how these groups can benefit from the available resources in order to enhance their abilities in learning a foreign language. It must be noted that every language learning situation could be unique and using an umbrella term such as 'foreign language context' is not necessarily adequate to describe a given language learning situation.

To do so, the following research questions were raised:

1) What kind of social resources do Iranian foreign language learners typically draw on?

2) What are the potential resources which can be made available to Iranian foreign language learners outside the classroom?

3) To what extent are Iranian foreign language learners acting as English resources for other language learners in their school, language institutes, or their families?

\section{Literature Review}

Two separate approaches are worth mentioning in here. The first approach is concerned with the conceptualization of language acquisition as the product of mental processes. This conceptualization, as Hoff (2006) puts it, has been taken into account in seminal works and texts since the 1960s (e.g., Chomsky, 1965; Crain \& Lillo-Martin, 1999; Hoff, 2003a, 2005). The other approach which puts emphasis on the social and cognitive development rather than the language development has its theoretical basis in the bioecological model of development, which focuses less on the internal processes underlying development; rather its emphasis is more on the shaping role of social context in which learners live and learn a language (Bronfenbrenner, 1979, 1988; Bronfenbrenner \& Morris, 1998; Tudge et al., 1997). Hoff (2006) holds that social contexts are considered as a nested set of systems surrounding the learners. Subsequently, combining these models of language acquisition and language development yields a model in which the procedure and mechanism of language acquisition exists in the head of the learner, while the learner resides in a system of social context (Hoff, 2006, p. 56). There are several lines of research carried out to describe the relationship between social context variables and the process of language development (Hoff-Ginsberg \& Shatz, 1982; Gallaway \& Richards, 1994).

Vygotsky (1962), a Russian psychologist, whose ideas have influenced the field of educational psychology in general and the field of education in particular, believes that although biological factors constitute the necessary pre-requisite for elementary processes to emerge, socio-cultural factors are also indispensable for elementary natural processes to develop (Turuk, 2008, p. 245). He lays emphasis on the significance of the social context and considers socio-cultural settings as the primary and determining elements in the development of higher forms of human mental activity, such as voluntary attention, intentional memory, logical thought, planning, and problem-solving. Introducing the concept of Zone of Proximal Development (henceforth, ZPD), which is considered as a remarkable contribution to the field of education and learning process, Vygotsky (1962) is concerned with the issue of individual's future growth and what she or he is not yet (Wertsch, 1985; Lantolf, 2002; Shayer, 2002). Vygotsky (1962) defines the concept of Zone of Proximal Development as "the distance between a child's actual developmental level, as determined by independent problemsolving, and the higher level of potential development as determined through problem-solving under adult guidance or in collaboration with more capable peers" Wertsch (1985, p. 60). In other words, Vygotsky (1962) believes that ZPD helps in determining a child's mental functions and procedures which are currently in the embryonic state to mature sooner or later. Moreover, he claims that the study of ZPD is also important, because it is the dynamic process in which the transition from interpsychological to intrapsychological functioning takes place. That is, as Turuk (2008) points out, what a child can do under the guidance of a significant other or through interaction, he or she will be able to do the same thing independently (p. 254).

For practical reasons, much of the literature on language learning has always tended to focus on the classroom context, or controlled experimental situations (Pica \& Doughty, 1998; Foster \& Skehan, 1996). However, Garner (1990) and McDermott (1993) believe that results and findings of the controlled situations cannot be generalized to other learning situations. Consequently, Tudor (2003) proposes the need for a more ecological perspective. He believes that an ecological perspective involves exploring language teaching and learning environment in which learners live and the procedure of the study is not carried out in isolation, but in a social context (Tudor, 2003). That is, the ecological 
perspective puts emphasis on the various human and contextual factors which influence the use and effectiveness of the procedures taking place during the language learning process.

Holliday (1994), Norton and Toohey (2003) and Palfreyman (2003) (as cited in Palfreyman, 2006) point out that "conceptualization of language learning in Applied Linguistics and ELT have tended to portray the language learner as a relatively decontextualized cognitive being (p. 34)." According to Oxford (1990), O'Malley and Chamot (1990), Wenden (1991), Dickinson (1992) and Oxford and Ehrman (1995), individual learners employ different kinds of strategies to learn both inside and outside the classroom setting. However, it seems that the context of which the language learner is a part is not taken into account (Palfrayman, 2006, p. 353). Furthermore, the strategies related to the social context, proposed by Oxford (1990), have been discussed less often in later works (e.g. Chamot \& O'Malley, 1996) than the cognitive and metacognitive strategies which are highly individual-centered. Then, if we take into account only the individualistic concept of a language learner, the role of context in the literature of the second language learning will be considered as a container (Lave, 1993). That is, context is only a backdrop for an individual learner, and is considered as a necessary factor to explain just the variation in individual performance. In contrast, Lave and Wenger (1991) proposed a situated learning approach which considers context and learner as shaping each other in all aspects of learning.

Regarding the significance of community and social context in language learning, Bransford et al. (2000) estimate that $79 \%$ of school pupils' waking time is spent interacting at home and community, compared with $21 \%$ at school. Putting emphasis on the significance of the environment beyond the school, these researchers call on educators and stakeholders to consider the educational potential of the community (Palfreyman, 2006). In a seminal study, Heath (1983) compares two working class communities and examines how children are socialized into a community of language practice through everyday interaction with text and their family members. Within SLA research, it is revealed that social parameters can also influence the motivation (Lamb, 2004) and learner autonomy (Palfreyman, 2003), although these concepts are considered as variables independent of social context (Palfreyman, 2006).

In the literature on language education, as Benson (2001) puts it, resources most often are considered as material resources which may include authentic materials, teaching materials, classroom equipment, and in a broad sense, funds. However, Brookfield (1980) pointed out that the way people learn something outside a formal educational setting did not operate simply as individuals, but relied on networks of other people who acted as models for the learner, or a source of support and feedback. Therefore, Norton (2000) and others, indicate the importance of social resources for learning in general and language learning in particular. Palfreyman (2006) holds that a learner is surrounded by people (teachers, other learners, friends, family members and so on) who may be more or less knowledgeable or supportive. As with the material resources, however, use and access to these resources may be more or less problematic.

Regarding the use of both material and social resources for second language learning, Palfreyman (2006) points out that in his study carried out in the UAE context, learners make use of a rich variety of material and social resources to practice English and to attempt to clarify their understanding of the language. The results of his study indicated that language learners in that context had access to a wide range of material resources for language learning, and they tended to favor entertaining and/or electronic resources (Palfreyman, 2006, p. 365).

\section{Materials and Methods}

\subsection{Participants}

The participants of the study were selected from Shiraz central branch of the Iran Language Institute (ILI), located on South Hemmat Street. To choose the subjects of the study, use was made of Morgan's formula (1970) which deals with the selection of samples from the exact number of subjects for a study. The participants for this study were 250 students, 180 males and 70 females, studying English at Intermediate, High, and Advanced levels. The majority of these participants were studying Mathematics and Physics, Experimental Sciences at high school or pre-university courses, and the rest was college students studying in different university majors. Of course, since the male students were readily available and were more interested in the study than the female ones, a large number of the participants, 180, were male, and just 70 of the them were female students. They all had Persian as their first language, and were aged between 18 and 40 and had similar language learning backgrounds. The participants came from a range of social and professional backgrounds and differed in the light of the reasons why they attended English language classes. In addition, it has to be mentioned that the data were gathered in February and May 2011 during the winter and spring semesters of the academic year at the Iran Language Institute in Shiraz, Iran. Since there was a semester break, the quantitative phase of the study was carried out during the winter, while the qualitative phase was carried out two months later during the spring semester.

In the current study, cluster sampling was used to select the participants from the main branch of ILI. Therefore, among the many classes of intermediate, high, and advanced levels, 15 intact classrooms were randomly selected, and the questionnaire was given to all the students in those classrooms. For the qualitative phase of the study, a number of the students were randomly selected from the 250 students who had completed the questionnaire to conduct a semistructured interview.

\subsection{Instruments}

In this study, two kinds of instruments were used. To gather the qualitative data, a questionnaire was administered to all randomly selected participants. The items in the questionnaire included questions on the resources available outside the class for language learning, and on learners' pattern of the use of these resources. The questionnaire began by trying to 
establish the kind of environment within which the learners live. Following that, the questions which were explicitly related to the language learning practice were posed.

The quantitative data from the questionnaire provided an overview of a large sample of students; however, in order to gain more in-depth individual data, a semi-structured interview checklist was conducted with a representative sample of the participants, randomly selected from those who had filled out the questionnaire. The interview questions were based on the questions posed in the original questionnaire as well as some other additional questions relevant to the potential language learning resources in the social context in which the students were living.

\subsection{Data Analysis}

In the present study, first, the Statistical Package for Social Sciences (SPSS) was used for analyzing the data, using both descriptive and inferential statistics. The chi-square test was used as the main statistical formula for analyzing the quantitative data. Then the qualitative data that came from the interviews were analyzed via specific interview analysis techniques (Kvale, 1996). Furthermore, since this study accounts for different questions about the social context of the language learners, for all of the research questions, the data were analyzed through both descriptive and inferential statistics.

\section{Results of the Study}

As far as the first research question is concerned, the statistics show that student spend a significant portion of their time with their family members, and more than half of them spend their time with their friends and classmates 'once a week' or 'a few times a week'. As can be seen in the table below, a large number of the students use the Internet messengers 'rarely' or 'once a week'. As it came out from the interview section of the study, the reason is that some of them either do not know how to use these resources as ways of language learning, or they cannot afford them.

Students also believed that with regard to the practice of the four language skills at home, they have very limited opportunities to engage with English, and just in some rare cases, they have to practice mostly the reading and writing skills, as their homework assignment. Moreover, they believed that in very few cases, they can find opportunities to practice the four language skills outside their home or the language institute where they study English. The statistics actually mirror the fact that these students do not have enough exposure or access to authentic English language in a specific foreign language context.

Table 1. Descriptive statistics for students' use of English at home

\begin{tabular}{cccccc}
\hline & Rarely & once a week & a few times a week & every day & Total \\
\hline 13 & $103(41.2 \%)$ & $40(16 \%)$ & $77(30.8 \%)$ & $30(12 \%)$ & 250 \\
\hline 14 & $69(27.6 \%)$ & $40(16 \%)$ & $91(36.4 \%)$ & $50(20 \%)$ & 250 \\
\hline 15 & $34(13.6 \%)$ & $39(15.6 \%)$ & $\mathbf{1 1 4}(\mathbf{4 5 . 6 \% )}$ & $63(25.2 \%)$ & 250 \\
\hline 16 & $67(26.5 \%)$ & $57(23 \%)$ & $94(38 \%)$ & $32(12.5 \%)$ & 250 \\
\hline
\end{tabular}

Table 2. Descriptive statistics for students' use of English outside home or institute

\begin{tabular}{cccccc} 
& rarely & once a week & a few times a week & every day & Total \\
\hline 17 & $\mathbf{1 4 9}(\mathbf{6 0 \%} \%)$ & $35(14 \%)$ & $53(21.5 \%)$ & $13(4.5 \%)$ & 250 \\
\hline 18 & $\mathbf{1 4 5 ( 5 8 \% )}$ & $45(18 \%)$ & $48(19.2 \%)$ & $12(4.8 \%)$ & 250 \\
\hline 19 & $\mathbf{1 2 5 ( 5 0 \% )}$ & $44(18.3 \%)$ & $62(25.7 \%)$ & $19(6 \%)$ & 250 \\
\hline 20 & $\mathbf{1 5 9}(\mathbf{6 4 \%} \%)$ & $35(14 \%)$ & $46(18.4 \%)$ & $10(3.6 \%)$ & 250 \\
\hline
\end{tabular}

Of course, a word of caution is necessary regarding the differences between various foreign language learning contexts, and that is that not all foreign language contexts are the same in terms of language learning opportunities.

With regard to the usefulness rate of the materials students use, most of them believed that entertaining materials such as watching English films, reading English story books and magazines, talking to foreigners in the city, and the like can be useful or very useful ways of practicing and learning English, rather than simply going through the grammar books or looking up words in dictionaries.

Table 3. Descriptive statistics for the usefulness rate of the materials used by the students

\begin{tabular}{cccccc}
\hline & not useful & a bit useful & useful & very useful & Total \\
\hline 21 & $20(8 \%)$ & $69(28 \%)$ & $115(46 \%)$ & $46(18 \%)$ & 250 \\
\hline 22 & $15(6 \%)$ & $37(15 \%)$ & $105(42 \%)$ & $93(37 \%)$ & 250 \\
\hline 23 & $22(9 \%)$ & $47(18.3 \%)$ & $111(45 \%)$ & $70(27.7 \%)$ & 250 \\
\hline 24 & $16(6.5 \%)$ & $30(12 \%)$ & $91(36.5 \%)$ & $\mathbf{1 1 3 ( 4 5 \% )}$ & 250 \\
\hline 25 & $8(3.5 \%)$ & $20(7.5 \%)$ & $62(25 \%)$ & $\mathbf{1 6 0 ( 6 4 \% )}$ & 250 \\
\hline 26 & $18(7.2 \%)$ & $48(19.2 \%)$ & $95(38 \%)$ & $89(35.6 \%)$ & 250 \\
\hline
\end{tabular}


As dictated by the objectives of the study, students provided some information about the people helping them with English at home. 34\% of the students said that older siblings help them with English at home; $22 \%$ reported that they would like to call their friends and classmates to seek help and $21 \%$ preferred not to seek help from others. They also believed that fathers are twice as helpful as mothers with their English.

Table 4. Descriptive statistics for the family members helping students with English at home

\begin{tabular}{|c|c|c|c|c|c|c|c|c|c|c|c|}
\hline & father & mother & $\begin{array}{c}\text { older } \\
\text { brother(s) }\end{array}$ & $\begin{array}{c}\text { older } \\
\text { sister(s) }\end{array}$ & $\begin{array}{l}\text { younger } \\
\text { brother(s) }\end{array}$ & $\begin{array}{l}\text { young } \\
\text { sister }\end{array}$ & $\begin{array}{l}\text { I friend \& } \\
\text { classmate }\end{array}$ & parents & siblings & nobody & Total \\
\hline 27 & $29(12 \%)$ & $14(6 \%)$ & $44(18 \%)$ & $40(16 \%)$ & 4 & 4 & $53(21 \%)$ & 5 & 3 & $54(22 \%)$ & 250 \\
\hline 28 & $33(13 \%)$ & $25(11 \%)$ & 13 & 12 & 10 & 2 & $146(59 \%$ & 5 & 2 & 2 & 250 \\
\hline 29 & 15 & $45(18 \%)$ & 5 & 1 & 20 & 9 & 4 & $130(52 \%$ & 21 & 0 & 250 \\
\hline 31 & $33(13 \%)$ & 23 & $42(17 \%)$ & $48(20 \%)$ & 9 & 6 & 0 & 8 & 4 & $77(31 \%)$ & 250 \\
\hline 33 & 0 & 2 & 2 & 4 & 16 & 7 & $135(54 \%$ & 23 & $54(22 \%)$ & 7 & 250 \\
\hline
\end{tabular}

They also indicated that if their problems with English persist, more than half of the students, 59\%, prefer to call their friends for help, and the rest asks their family members for help. In addition, more than half of the students, $52 \%$, prefer not to ask their parents their English problems. Of course, mothers with $6 \%$ of help are the least frequently source of help with English at home.

Regarding the question "Who do students mostly help?", more than half of them, 54\%, believed that they help their friends and classmates, and $22 \%$ said that they provide help for their younger siblings at home. Furthermore, with regard to the amount of help given and taken between students, family members, and friends, 32\% of the participants believed that they 'never' receive help from others, and $38 \%$ believed that they 'rarely' receive help from others with regard to English problems. However, most of the students, 41\%, believed that they 'sometimes' provide help for others, and 36\% said that they 'often' help others with English either at home, or at their institute.

Table 5. Descriptive statistics for the amount of help given or taken between students and their family members and friends regarding English Language problems

\begin{tabular}{cccccc} 
& Never & Rarely & sometimes & often & Total \\
\hline 30 & $\mathbf{7 9 ( 3 2 \% )}$ & $\mathbf{9 5 ( 3 8 \% )}$ & $54(22.3 \%)$ & $22(7.7 \%)$ & 250 \\
\hline 32 & $10(4 \%)$ & $48(19 \%)$ & $\mathbf{1 0 3}(\mathbf{4 1} \%)$ & $\mathbf{8 9 ( 3 6 \% )}$ & 250
\end{tabular}

To answer the second research question, four themes were extracted from the interview data, using qualitative content analysis: Internet webs, English films and music, satellite programs, and language learning software. The Internet webs were one of the most important resources available to Iranian language learners, and include such websites as Yahoo, Google, Bing, and the like.

The third research question was about the extent to which Iranian foreign language learners behave as English resources for other language learners in their school, language institutes, or their families.

Table 6. Descriptive statistics for the amount of help students give to other language learners in an institute or school and their family members at home

\begin{tabular}{lllll}
\hline & never & Rarely & Sometimes & Often \\
\hline 32 & $10(4 \%)$ & $48(19 \%)$ & $\mathbf{1 0 3 ( 4 1 \% )}$ & $\mathbf{8 9}(\mathbf{3 6 \%})$ \\
\hline
\end{tabular}

The results suggest that a large number of the participants provide help for others at home or institute, whereas they do not receive a great amount of help from others with English problems. 


\section{Discussion}

The results indicated that the students spend more time with their family members who are not familiar with English language, and may not have high academic education. Therefore, they are not knowledgeable enough in order to be able to help their children with English language problems. In this regard, Borgatti and Cross (2003) also mentioned that one would expect parents and younger siblings to be a limited source of help with English in an EFL setting, owing to lack of knowledge of English.

In his study carried out in UAE context, Palfreyman (2006) pointed out that since English use outside the home occurs mainly in public contexts where English is prevalent, speaking (49\% 'every day') and listening (42\%) are cited more than reading (31\%) and writing (22\%). However, in the current study carried out in the Iranian context, students do not have a rich context of English in order to practice English outside the classroom or home. The statistics show that speaking (4\% 'every day'), listening (4\%), reading $(6 \%)$, and writing $(4 \%)$ skills are practiced as little as possible, outside the home or language institute, in the Iranian social context as a foreign language learning context.

More than $70 \%$ of the participants believed that an English-English dictionary, reading stories, magazines, and newspapers, chatting on the Internet, using Web Pages are 'useful' or 'very useful'. Furthermore, more than $80 \%$ of the participants believed that watching English films for learning English is 'useful' or 'very useful'. However, traditional resources such as grammar books are rated as less useful.

These entertainment/communicatively oriented resources are reminiscent of Willing's (1988) 'communicative' learning orientation which accounts for the enhancement of the students' communicative and learning abilities. Then, it can be inferred that this is the case for the current study as well. Besides, Palfreyman (2006) also holds that his participants in the UAE context rated these entertainment/communicatively oriented resources as the most useful resources for learning English.

It appears that most of the students seek help with English from others at home less often, while they offer help to other family members. To be specific, only $30 \%$ of the respondents said that they receive help from others at home 'sometimes' or 'often', whereas $77 \%$ of them gave a similar response regarding helping others 'sometimes' or 'often'. Therefore, it seems that, a considerable number of the students are more proficient in English among their family members and classmates.

Similar to these findings, Palfreyman (2006) also found that most of the time the participants in the UAE context offer help to other family members rather than receive help from them. He holds that " $72 \%$ of respondents said that they consulted others at home 'sometimes' or 'often', but $92 \%$ of them gave a similar response regarding helping others. Therefore, it seems that, at least as far as students themselves perceive the situation, they have somewhat of an "English broker" role in the family" (Palfreyman, 2006, p. 364).

Therefore, it can be concluded that peer group activities can be considered as a valuable source of help for English language learning in the Iranian context. This is because in the majority of the cases, students tend to resort to their friends and classmates in order to deal with the English problems they encounter. In this regard, prominent researchers such as Vygotsky (1962), Wertsch (1985), Ellis (1994), Lantolf (2000), to name just a few, believe that group work and cooperation can be of paramount significance in different aspects of learning during the life span of learners in general and language learners in particular.

\section{Conclusion}

The main purpose of this study was to investigate the resources available to Iranian foreign language learners, the potential resources in their context, and the extent to which they are considered as a source of help for others with regard to English language learning. According to the results of the study, it can be pointed out that the resources on which Iranian foreign language learners usually rely are not so vast. That is, students mostly resort to resources such as English films, English story books or magazines, and some Internet websites. Family members are considered as the least helpful sources of help for language learning at home. Of course, in some cases, older siblings are mentioned as limited sources of help with English. Furthermore, some potential resources such as Internet messengers, English language learning software and DVDs were also introduced, which the majority of the students are not necessarily aware of. It was also revealed that language learners themselves are a great source of help for other language learners at home or at their language institute regarding any language learning activity or practice.

\section{References}

Benson, P. (2001). Teaching and Researching Autonomy in Language Learning. Longman, London.

Borgatti, S., Cross, R., (2003). A relational view of information seeking and learning in social networks. Management Science 49, 432-445.

Bransford, J.D., Brown, A.L., \& Cocking, R.R. (Eds.), (2000). How People Learn: Brain, Mind, Experience. National Academy Press.

Bronfenbrenner, U. \& Morris, P. A. (1998). The ecology of developmental processes. In W. Damon (Series Ed.) \& R. M. Lerner (Vol. Ed.), Handbook of child psychology, Vol. 1: Theoretical models of human development $\left(5^{\text {th }}\right.$ ed., pp. 993-1028). New York: Wiley. 
Bronfenbrenner, U. (1979). The ecology of human development: Experiments by nature and design. Cambridge, MA: Harvard University Press.

Bronfenbrenner, U. (1988). Interacting systems in human development. Research paradigms: present and future. In N. Bolger, A. Caspi, G. Downey, \& M. Moorehouse (Eds.), Persons in context: Developmental Processes (pp. 25-49). New York: Cambridge University Press.

Brookfield, S. (1980). Independent adult learning. Studies in Adult Education 13 (1), 1-14.

Brown, H. D. (2001). Teaching by principles, an integrative approach to language pedagogy. (Second Edition). White Plains, NY: Pearson Education.

Chamot, A.U., O'Malley, J.M., (1996). Implementing the cognitive academic language learning approach (CALLA). In: Oxford, R. (Ed.), Language Learning Strategies around the World: Cross-Cultural Perspectives. University of Hawaii Press, Manoa, pp, 23-65.

Chomsky, N. (1965). Aspects of the theory of syntax. Massachusetts Institute of Technology.

Crain, S., \& Lillo-Martin, D. (1999). An introduction to linguistic theory and language acquisition. Oxford: Blackwell Publishers.

Dickinson, L., (1992). Learner autonomy 2: Learner Training for Language Learning. Authentik, Dublin.

Ellis, R. (1994). The study of second language acquisition. Oxford: Oxford University Press.

Foster, P., Skehan, P., (1996). The influence of planning and task types on second language performance. Studies in Second Language Acquisition 18, 299-324.

Gallaway, C., \& Richards, B. J. (1994). Input and interaction in language acquisition. Cambridge: Cambridge University Press.

Garner, R., (1990). When children and adults do not use learning strategies: toward a theory of settings. Review of Educational Research 60 (4), 517-529.

Heath, S. B., (1983). Ways with Words: Language, Life and Work in Communities and Classrooms. Cambridge University Press, New York.

Hoff, E. (2003a). Language development in childhood. In R. M. Lerner, M. A. Easterbrooks,

\& J. Mistri (Eds.), Handbook of psychology. Developmental psychology (Vol. 6, pp. 171-193). New York: Wiley.

Hoff, E. (2005). Language development. Belmont, CA: Wadsworth/Thomson Learning.

Hoff, E. (2006). How Social Contexts Support and Shape Language Development. Developmental Review, 26, 55-88.

Hoff-Ginsberg, E., \& Shatz, M. (1982). Linguistic input and the child's acquisition of language. Psychological Bulletin, 92, 3-26.

Holliday, A., (1994). Appropriate Methodology and Social Context. Cambridge University Press, Cambridge.

Kvale, S. (1996). Interviews: An Introduction to Qualitative Research Interviewing. Thousand Oaks: Sage Publication.

Lamb, M. (2004). Integrative motivation in a globalizing world. System 32 (1), 3-20.

Lantolf, J.P., (2000). Introducing sociocultural theory. In: Lantolf, J. P., (Ed). Sociocultural theory and second language learning. Oxford University Press, pp.1-26.

Lave, J., (1993). The practice of learning. In: Chaiklin, S., Lave, J. (Eds.), Understanding Practice: Perspectives on Activity and Context. Cambridge University Press, pp 444-531

Lave, J., Wenger, E., (1991). Situated Learning. Cambridge University Press, pp. 23-56.

McDermott, R., (1993). The acquisition of a child by a learning disability. In: Lave, J., Chaiklin, S. (Eds.), Understanding Practice: Perspectives on Activity and Context. Cambridge University Press, Cambridge, pp. 269-305.

Norton, B., Toohey, K., (2003). Learner autonomy as agency in sociocultural settings. In Palfreyman, D., Smith, R.C. (Eds.), Learner Autonomy Across Cultures: Language Education Perspectives. Palgrave Macmillan, London, pp 124206.

O’Malley, J.M., Chamot, A.U., (1990). Learning Strategies in Second Language Acquisition. Cambridge University Press, Cambridge.

Oxford, R., (1990). Language Learning Strategies: What Every Teacher Should Know. Heinle and Heinle, Boston.

Oxford, R.L., Ehrman, M.E., (1995). Adults' language learning strategies in an intensive foreign language program in the United States. System 23, 359-386.

Palfreyman, D. (2006). Social Context and Resources for Language Learning. System, 34, 352-370.

Palfreyman, D., (2003). Expanding the discourse on learner development: a reply to Anita Wenden. Applied Linguistics (24/2), 243-248.

Pica, T., Doughty, C., (1988). Variation in classroom interaction as a function of participation pattern and task. In: Fine, J. (Ed.), Second Language Discourse (pp. 82-105). Ablex, Norwood, NJ. 
Shayer, M., (2002). Not just Piaget, not just Vygotsky, and certainly not Vygotsky as an alternative to Piaget. In: Shayer, M., (Ed). Learning intelligence, cognitive acceleration across the curriculum from 5 to 15 years. UK: Open University Press.

Spolsky, B., Gem, J.B. and Read, J. (1974). A Model for the Description, Analysis, and Perhaps Evaluation of Bilingual Education. Navajo Reading Study Progress Report No. 23. Albuquerque, N.M.: University of New Mexico.

Stern, H.H. (1983). Fundamental Concepts of Language Teaching. Oxford University Press.

Tudge, J., Gray, J. T., \& Hogan, D. M. (1997). Ecological perspectives in human development: A comparison of Gibson and Bronfenbrenner. In J. Tudge, M. J. Shanahan, \& J. Valsiner (Eds.), Comparisons of human development: Understanding time and context (pp. 72-105). Cambridge: Cambridge University Press.

Tudor, I., (2003). Learning to live with complexity: towards an ecological perspective on language teaching. System 31 , $1-12$.

Turuk, M, C. (2008). The Relevance and Implications of Vygotsky's Sociocultural Theory in the Second Language Classroom. ARECLS, 5, 244-262.

Vygotsky, L. S. (1962). Thought and Language. Cambridge, Massachusetts, the M.I.T.

Wenden, A., (1991). Learner Strategies for Learner Autonomy. Prentice Hall, Englewood Cliffs.

Wertsch, J., (1985). Vygotsky and the social formation of mind. UK: Harvard University Press.

Wertsch, J., (1985). Vygotsky and the social formation of mind. UK: Harvard University Press.

Willing, K., (1988). Learning Strategies in Adult Migrant Education. National Curriculum. 